\title{
Hair dyes as a risk for autoimmunity: from systemic lupus erythematosus to primary biliary cirrhosis
}

\author{
Daniel Smyk • Eirini I. Rigopoulou • \\ Nicola Bizzaro $\cdot$ Dimitrios P. Bogdanos
}

Received: 19 August 2011/Accepted: 17 October 2011/Published online: 13 January 2012

(C) Springer-Verlag 2012

\begin{abstract}
Environmental and genetic factors appear to be involved in the pathogenesis of primary biliary cirrhosis (PBC), a chronic cholestatic liver disease characterized by immune-mediated destruction of the small and medium sized intrahepatic bile ducts. Environmental factors include exposure to various infectious, xenobiotic and chemical compounds. These exposures may occur occupationally, through water or air contamination, pharmacological administration or by elective exposure, to name a few. Hair dyes are compounds that have been implicated in the development of several autoimmune diseases, including systemic lupus erythematosus (SLE) and PBC. So far, only epidemiological studies have addressed the role of hair dyes in PBC, with limited results. Hair dyes in SLE have been examined, and have recently demonstrated an association, both epidemiologically and immunologically. This follows a series of negative studies, which may not have taken into account several features of hair dye use. This review will examine the literature surrounding hair dye use and SLE, and compare this to data surrounding PBC.
\end{abstract}

D. Smyk · D. P. Bogdanos ( $\square)$

Institute of Liver Studies and Liver Unit, Transplantation Immunology and Mucosal Biology,

King's College London, School of Medicine, King's College

Hospital, Denmark Hill Campus, London SE5 9RS, UK

e-mail: dimitrios.bogdanos@kcl.ac.uk;

dimitrios.bogdanos@nhs.net

URL: http://www.bogdanoslab.com

E. I. Rigopoulou

Department of Medicine, University of Thessaly Medical

School, Thessaly, Mezourlo, 41222 Larissa, Greece

N. Bizzaro

Laboratorio di Patologia Clinica, Ospedale Civile,

Tolmezzo, Italy
Treating physicians should be prepared for questions surrounding the need to take precautions against repeated hair dye use and this topic is discussed further.

Keywords Autoantibody · Autoimmunity - Cosmetics · Autoimmune disease · Environment · Genetics · Immunopathogenesis · Risk factors · Susceptibility
Abbreviations
AMA Antimitochondrial antibody
ANA Antinuclear antibody
PBC Primary biliary cirrhosis
PPD $\quad P$-phenylenediamine
SLE Systemic lupus erythematosus
UDCA Urseodeoxycholic acid

\section{Introduction}

Environmental factors combined with genetic susceptibility are largely believed to be essential working partners in the development of autoimmune disease [1-4]. The term 'environmental factors' or 'environmental agents' in the discussion of the pathogenesis of autoimmune disease, is a blanket term to address environmental components such as microbial agents, vaccines, diet, drug exposure, heavy metals, ultraviolet radiation and smoking, among many others [3-9]. Monozygotic concordance rates below $50 \%$ are indicative that environment as well as genetics are involved [10-13]. As well, studies on genetically similar populations living under different conditions have demonstrated different incidence rates of autoimmune disease. The induction of autoimmune disease by these exposures may be through various mechanisms such as the alteration of autoantigen structure, altered expression of 
antigens, stimulatory effects on the immune system, T-cell dysregulation, apoptosis-mediated autoimmunity, molecular mimicry and immunological cross-reactivity [5, 14-18].

Cigarette smoking is one example of non-infectious agents which have been studied in rheumatoid arthritis (RA), autoimmune thyroiditis, inflammatory bowel disease, and primary biliary cirrhosis (PBC) [19-22]. Cigarette smoke has been shown to increase the production of pro-inflammatory cytokines, and reduce the levels of anti-inflammatory cytokines. Free radicals contained in cigarette smoke can provoke cellular destruction and release of intracellular autoantigens. Various toxins found within cigarette smoke may cause DNA damage and genetic mutations, as well as stimulate autoreactive T cells [21]. An alteration in oestrogen metabolism, which has been indicated as a feature in autoimmune disease, has also been found to occur in active smokers [23, 24]. However, the effect of tobacco smoke in the loss of self-tolerance may be more complicated, as it appears that smoking abstinence exacerbates gastrointestinal symptoms in patients with ulcerative colitis (UC). Such an effect has not been noted in patients with Crohn's disease, the other major inflammatory bowel disease.

Silica exposure has also been investigated as a factor involved in autoimmune disease [12, 25, 26]. Silica has been linked with scleroderma, RA, vasculitis and systemic lupus erythematosus (SLE) [12, 25, 26]. Silica acts as an immune stimulant, increasing pro-inflammatory cytokine production, as well as inducing apoptosis and necrosis [12, 25, 26]. Interestingly, silica has also been shown to increase autoantibody production [27] and immune complex formation in animal models. Animals exposed to silica have demonstrated increases in B and CD4 T cell counts, as well as altering $\mathrm{T}$ helper and $\mathrm{T}$ regulatory cell ratios [28]. Apart from silica, exposure to solvents such as trichloroethylene, mineral spirits, and petroleum based products have been linked to scleroderma and other undifferentiated connective tissue diseases [29].

Primary biliary cirrhosis is one autoimmune disease in which multiple environmental factors have been implicated. Hair dyes have been added to this list, but very few studies address these compounds. Hair dyes have been previously explored in relation to SLE, both epidemiologically and immunologically. This review will examine the literature surrounding the use of hair dyes in SLE in relation to PBC. As PBC and SLE very rarely co-occur in an affected individual, the effect of hair dyes in either disease may help us understand the complex role of these compounds as environmental triggers of autoimmunity.

\section{Primary biliary cirrhosis}

PBC is a chronic cholestatic liver disease of autoimmune origin, characterised by inflammatory destruction of the small intrahepatic bile ducts, fibrosis progressing to cirrhosis and subsequent liver failure [30-32]. Many patients are asymptomatic at the time of diagnosis [33-35]. PBC is characterised by anti-mitochondrial (AMA) and diseasespecific antinuclear antibody (ANA), which are also found in asymptomatic patients with normal or abnormal biochemical blood tests indicating cholestasis [30, 34, 36-38]. The most common presenting symptoms are those of fatigue, pruritus and arthralgias [30, 34, 39]. More severe presenting symptoms are related to portal hypertension and hepatic decompensation (jaundice, ascites or variceal bleeding), leading to the need for liver transplantation [30, 34, 39]. However, North American and European studies indicate that the percentage of patients with $\mathrm{PBC}$ who require liver transplantation has fallen significantly [32]. In general, the course of PBC is slow but unpredictable [30, 34, 35, 39]. Early treatment with urseodeoxycholic acid (UDCA) has greatly improved survival rates and quality of life in PBC patients [30-32]. Whether UDCA is solely anticholestatic or is also immunomodulatory is to be established [30, 32, 40, 41].

PBC is diagnosed on the basis of AMA in serum, biochemical markers of cholestasis, and histological features diagnostic or compatible with PBC [30-32]. Biochemical indices of cholestasis include increased levels of alkaline phosphatase and $\gamma$ GT [30-32]. AMA and disease-specific ANA are usually present at high titres [30, 36-38]. Occasionally, some patients are found to be negative for AMA [36, 37, 42-47]. AMA titres do not appear to correlate with the severity of the disease and do not seem to have any known clinical significance. Disease-specific ANA appear to be able to identify $\mathrm{PBC}$ patients with a more aggressive disease [36-38, 44, 48-59]. PBC specific ANA patterns detected by indirect immunofluorescence, include the "multiple nuclear dot" and "nuclear membrane/rim like" patterns [37, 38, 54, 60-62]. The "multiple nuclear dot" pattern is given by antibodies directed against nuclear body proteins such as Sp100, Sp140, promyelocytic leukaemia nuclear body proteins, and small ubiquitin-like modifiers [30, 37, 38, 50, 56, 57, 59, 63-68]. The "nuclear envelope/ rim like pattern" corresponds to reactivities specific for gp210 and nucleoporin p62 and other less studied antigens of the nuclear membrane [54]. Up to $50 \%$ of PBC patients are positive for these patterns in isolation or in combination, compared to less than $1 \%$ of the pathological and healthy controls indicating their significant disease specificity $[1,54,57]$. Immunoglobulin $\mathrm{M}(\operatorname{IgM})$ is usually found to be raised. Histological features typical for PBC include destruction of biliary epithelial cells and loss of small bile ducts with portal inflammatory cell infiltration [30-32].

The mechanisms responsible for the induction of autoimmunity are poorly understood. Several articles published in this, as well as previous issues of the journal, are 
focusing on the investigation of mechanisms inducing autoimmunity and indeed autoimmune disease [18, 69-83]. The mechanism of molecular mimicry and immunological cross-reactivity between infectious agents or xenobiotics and disease-specific autoantigens has been used to explain the loss of immunological tolerance in autoimmune gastrointestinal and liver diseases, including PBC [84-100].

Several environmental factors have been also implicated in the development of PBC [6, 40, 41, 84, 92, 101-108]. These have included recurrent urinary tract infections [109, 110], xenobiotics [111, 112], and oestrogen deficiency [20, 113] to name a few. Clustering of PBC cases in New York State [114], and the north of England [115] raise further suspicion of environmental factors being involved [6, 104].

\section{Epidemiological studies in PBC and hair dyes use}

Epidemiological studies on PBC have demonstrated varying results as to whether hair dye use is a factor in the development of PBC. A French study involving 222 PBC patients and 509 controls was based on a questionnaire of 200 questions covering medical, surgical and reproductive history, demographics and lifestyle [116]. Although exposure to cigarette smoke was found to be associated with PBC, hair dye use was not [116]. In the PBC group, it was found that the average exposures per year was $3.4( \pm 4.6)$, which was not significantly different from the control group with the average number of exposures being 3.5 $( \pm 4.5)$ [116]. A much larger study from the US involved 1,032 PBC patients and 1,041 controls matched for sex, age, race and geographical location [20]. The PBC cohort consisted of patients from 23 tertiary care centers for liver disease across the US [20]. Controls were obtained from random-digit dialing of individuals with listed phone numbers [20]. All participants were given a questionnaire by trained personnel, which evaluated social, demographic, personal and family medical histories, lifestyle, and reproductive factors. PBC patients were found to have used hair dyes more frequently than controls (38 times per year compared to 35 times per year) [20]. Nail polish use was also found to be associated with PBC, and of note, the authors indicated that this involved female cases only, which does not appear to be the case with hair dyes [20]. A large epidemiological study from the UK has also found an association between PBC and hair dyes [113]. That study involved two cohorts of PBC patients, with one group consisting of 318 patients in an epidemiological group, and 2,258 patients from a PBC support group [113]. The control group was composed of 2,438 age and sex matched controls. All participants were sent a postal questionnaire on PBC risk factors. An association between hair dye use and $\mathrm{PBC}$ was found in both groups of PBC patients. Hair dye use preceded PBC diagnosis in $86 \%$ of the epidemiological PBC cases, and $87 \%$ of cases from the support group [113]. It should also be noted that $50 \%$ of women in all test groups reported previous hair dye use, compared to only $1 \%$ of male participants [113].

These epidemiological studies do not appear to analyze the relation of hair dyes with PBC separately in women and men with this disease. In fact, it does not appear that an analysis of hair dye use was limited to females in any epidemiological study of PBC, unlike studies on hair dye use in SLE [117-125]. As well, many epidemiological reports do not indicate the time length of hair dye use, and very few indicate whether hair dye use preceded the diagnosis of PBC.

\section{Hair dyes in SLE}

Much like PBC, several pharmacological and chemical materials have been implicated in the development of SLE, including exogenous sex hormones, silica, silicone, solvents, pesticides, mercuric chloride and hair dyes [121]. Hair dyes are of particular interest, as they contain aromatic amines that have been found to induce SLE-like symptoms [123]. An early case study by Freni-Titulaer et al. [119] indicated a positive association between the use of hair dyes and connective tissue disease. A larger study was carried out by Petri and Allbritton [122] involving 218 SLE patients from the Hopkins Lupus Cohort, who were asked to fill in a questionnaire on hair product use. Controls were administered the same questionnaire, and consisted of two groups, the first being 178 first and second degree relatives, and the second being 168 best friends of the patients [122]. That study found no significant relationship between hair dye use and the development of SLE [122]. In a prospective study of 106,391 patients, patients and controls were assessed (based on self-reporting) on hair dye use every 2 years, from 1976 to 1982 [125]. Again, no association was found, even in women with more than 15 years of hair dye use [125]. A longitudinal study by Jimenez-Alonso and colleagues [120] examined whether hair dyes played a role in the prognosis and course of SLE. That study was comprised of 91 SLE and 22 cutaneous lupus patients, divided into non-hair dye users, permanent users, and users but not permanent ones (indicating occasional use, such as bleaching or lowlights) [120]. No significant difference was found in relation to a more severe disease course in the two groups which used hair dyes, and in fact, non-users had more renal involvement than the two user groups [120].

Earlier studies into hair dyes and SLE largely pointed away from hair dyes being involved, however more recent studies have drawn attention back to hair dyes, with an 
examination of the immunemodulatory effects of hair dye use. A study by Cooper and colleagues [117] into SLE and hair dye use, subdivided hair dye use into dyes and permanent compounds, as well as limiting their analysis to females, due to the extremely low usage of hair dyes among males. Two hundred and sixty-five SLE patients were obtained from 34 rheumatology practices in Eastern and Southern Carolina, with 355 age, sex, and geographically matched controls obtained through a drivers licence registry [117]. Both smoking and hair dye use were assessed through a 60 min interview. No association between SLE and smoking was found, however, permanent hair dye use was associated with a small increase in the risk of developing SLE, especially if they had used dark coloured dyes [117]. This association increased with a longer duration of use, and there was little evidence of an association with temporary use, or the use of hair straighteners [117]. As ANA is the serological hallmark of SLE, Cooper et al. [118] examined the association between ANA positivity and exposure to environmental toxins, including hair dyes. Serum samples from 266 population-based subjects were obtained, as were occupational and hair dye usage histories [118]. Positivity for ANA was found in $21(8 \%)$ subjects, with an increased prevalence found in those who had been exposed to silica, dust, pesticides and UV radiation, and a smaller association was found with hair dye usage [118].

The immunological effects of hair dye usage have been examined recently in a study by Rubin and colleagues [124], who studied the immune responses in mice repeatedly exposed to $p$-phenylenediamine (PPD), which is a component of many hair dyes. Mice had PPD applied to the dorsum of their ears, which was washed away after $30 \mathrm{~min}$, which was done over several weeks [124]. The same was done for controls, which were exposed to a mixture of olive oil and acetone [124]. Analyses were conducted over several weeks, in which the area of application was histologically examined, and lymph node extracts were analysed by flow cytometry [124]. Increased cellular infiltration was seen after multiple exposures, with the inflammatory response peaking after 4 weeks of exposure to PPD [124]. After 4 weeks, it appeared that the inflammatory response levelled off, indicating that a balance between pro and antiinflammatory mechanisms had occurred [124]. Flow cytometry demonstrated increased proliferation of both CD4+ and CD8 + T cells in mice exposed to PPD, with the number of Th1 cells increasing with increased numbers of exposure [124]. CD4+Foxp3+ $\mathrm{T}$ regulatory (Treg) cells gradually increased up to the fourth week of exposure, at which point they outnumbered the IFN $\gamma$ and IL-17 producing $\mathrm{T}$ cells, and comprised $14 \%$ of the total CD4+ population [124]. A second series of analyses were conducted with hair dyes (as opposed to PPD alone), which produced similar results, with the exception that there was a higher Treg increase seen after hair dye exposure [124]. The above studies have demonstrated that hair dye use can induce a pro-inflammatory immune response, as well as possibly influencing the autoantibody profile. It appears also that dye use may indeed lead to the manipulation of suppressor mechanism which depending on the timing may have an anti-inflammatory effect. As well, studies which took into account the higher female preponderance of hair treatment usage, in addition to examining various product types, demonstrated a positive association between SLE and hair product usage.

\section{Hair dyes as a risk for PBC: time to revisit?}

Studies examining the association between PBC and hair dyes have been, at best, limited. Several factors addressed in the analysis between hair dye use and SLE, have not been addressed in PBC. First, epidemiological studies do not appear to separate male from female PBC patients, which may lead to an inaccurate prevalence of hair dye use. Accepted risk factors for $\mathrm{PBC}$, such as recurrent urinary tract infections and oestrogen deficiency, have been analysed with the factor of female preponderance being taken into account, but it is not clear as to whether this has been done in regards to hair dyes. As well, they do not appear to define various types of hair dyes, such as dark or light colourings, as well as products used to straighten hair. Nor do they address in detail the length of time that the patients used the hair products for. Refinement of studies to address these issues in SLE demonstrated a positive association between exposure and disease.

Immunological studies have found an increase proinflammatory response in mice exposed to PPD and hair dyes, which was followed by an increased regulatory $\mathrm{T}$ cell response [124]. An increase in CD4+Foxp3+ Tregs has also been demonstrated in peripheral blood mononuclear cells of PBC patients, also with increased IFN $\gamma$ [126]. Altered Treg function has been demonstrated to be a feature of PBC, or PBC-like pathology [127-130]. It could be argued that exposure to chemical compounds may induce pro-inflammatory and anti-inflammatory responses, the former prevailing in genetically susceptible individuals, thus contributing to the development of autoimmune disease. It would be of interest to see if any liver pathology is present in animal models of hair dye exposure.

\section{Hair dyes as a risk for advanced PBC: simple questions, straight answers}

A significant proportion of patients with $\mathrm{PBC}$ are aware of the current research surrounding PBC risk factors. 
This information is readily available on the internet, as well as in support groups for PBC patients. As a result, treating physicians should be prepared for questions surrounding the need to take precautions against risk factors, such as repeated hair dye use. In our practice, we ensure that patients are aware that the number of studies performed, as well as the small cohort sizes, prohibits any definitive conclusions from being made. We also make clear to the patient, that the cessation of hair dye use will likely not alter the course of their disease. It needs to be clarified that there are no data to suggest that the continuous exposure to synthetic dyes leads to more advanced disease. We do not encourage patients with PBC to follow any specific instructions, and avoid making any recommendations or advice concerning specific products. Patients with chemical sensitivities or allergies to unspecified chemical compounds are advised to follow conventional precautions applied for everyone. In a culture obsessed with beauty, youth and wellbeing, changing hair colour has become very common. There is no doubt that hair dye use will continue among men and women despite the potential risks, and it is likely that PBC patients are not the exception.

\section{Conclusion}

The list of chemical compounds implicated in the development of autoimmune disease is immense. Hair dyes have demonstrated an association with SLE development, but only after study refinement. It is apparent that when taking into account environmental components in the induction of the disease, care must be given to analyse those results in the context of the study population. Hair dyes are predominantly used by women, and studies must take this into account. As well, the variety of products available must also be addressed, as variability within a compound group may give differing results. These factors are likely to be involved in the limited studies associating hair dye use with PBC. As well, animal models may clarify the immunological mechanisms involved in the process of $\mathrm{PBC}$ induction and exposure to chemical compounds.

Conflict of interest None of the authors has a conflict of interest to declare.

\section{References}

1. Mackay IR (2005) The etiopathogenesis of autoimmunity. Semin Liver Dis 25(3):239-250

2. Wandstrat A, Wakeland E (2001) The genetics of complex autoimmune diseases: non-MHC susceptibility genes. Nat Immunol 2(9):802-809

3. Maverakis E, Miyamura Y, Bowen MP, Correa G, Ono Y, Goodarzi H (2010) Light, including ultraviolet. J Autoimmun 34(3):J247-J257
4. Molina V, Shoenfeld Y (2005) Infection, vaccines and other environmental triggers of autoimmunity. Autoimmunity 38(3): 235-245

5. Bach JF (2005) Infections and autoimmune diseases. J Autoimmun 25:74-80

6. Smyk D, Rigopoulou EI, Baum H, Burroughs AK, Vergani D, Bogdanos DP (2011) Autoimmunity and environment: am I at risk? Clin Rev Allergy Immunol. doi:10.1007/s12016-0118259-x

7. George J, Levy Y, Shoenfeld Y (1997) Smoking and immunity: an additional player in the mosaic of autoimmunity. Scand $\mathbf{J}$ Immunol 45(1):1-6

8. D'Cruz D (2000) Autoimmune diseases associated with drugs, chemicals and environmental factors. Toxicol Lett 112-113: 421-432

9. Fournie GJ, Mas M, Cautain B, Savignac M, Subra JF, Pelletier L, Saoudi A, Lagrange D, Calise M, Druet P (2001) Induction of autoimmunity through bystander effects. Lessons from immunological disorders induced by heavy metals. J Autoimmun 16(3):319-326

10. Leslie RD, Hawa M (1994) Twin studies in auto-immune disease. Acta Genet Med Gemellol (Roma) 43(1-2):71-81

11. Selmi C, Mayo MJ, Bach N, Ishibashi H, Invernizzi P, Gish RG, Gordon SC, Wright HI, Zweiban B, Podda M, Gershwin ME (2004) Primary biliary cirrhosis in monozygotic and dizygotic twins: genetics, epigenetics, and environment. Gastroenterology 127(2):485-492

12. Cooper GS, Wither J, Bernatsky S, Claudio JO, Clarke A, Rioux JD, Fortin PR (2010) Occupational and environmental exposures and risk of systemic lupus erythematosus: silica, sunlight, solvents. Rheumatology (Oxford) 49(11):2172-2180

13. Jarvinen P, Aho K (1994) Twin studies in rheumatic diseases. Semin Arthritis Rheum 24(1):19-28

14. Christen U, Hintermann E, Holdener M, von Herrath MG (2010) Viral triggers for autoimmunity: is the 'glass of molecular mimicry' half full or half empty? J Autoimmun 34(1):38-44

15. Bogdanos DP, Lenzi M, Okamoto M, Rigopoulou EI, Muratori P, Ma Y, Muratori L, Tsantoulas D, Mieli-Vergani G, Bianchi FB, Vergani D (2004) Multiple viral/self immunological crossreactivity in liver kidney microsomal antibody positive hepatitis $\mathrm{C}$ virus infected patients is associated with the possession of HLA B51. Int J Immunopathol Pharmacol 17(1):83-92

16. Bogdanos DP, McFarlane IG (2003) Cytochrome P450 2A6 meets P450 2D6: an enigma of viral infections and autoimmunity. J Hepatol 39(5):860-863

17. Lleo A, Selmi C, Invernizzi P, Podda M, Gershwin ME (2008) The consequences of apoptosis in autoimmunity. J Autoimmun 31(3):257-262

18. Alunno A, Bartoloni E, Nocentini G, Bistoni O, Ronchetti S, Petrillo MG, Riccardi C, Gerli R (2010) Role of regulatory T cells in rheumatoid arthritis: facts and hypothesis. Autoimmun Highlights 1(1):45-51

19. Costenbader KH, Karlson EW (2006) Cigarette smoking and autoimmune disease: what can we learn from epidemiology? Lupus 15(11):737-745

20. Gershwin ME, Selmi C, Worman HJ, Gold EB, Watnik M, Utts J, Lindor KD, Kaplan MM, Vierling JM (2005) Risk factors and comorbidities in primary biliary cirrhosis: a controlled interviewbased study of 1,032 patients. Hepatology 42(5):1194-1202

21. Arnson Y, Shoenfeld Y, Amital H (2010) Effects of tobacco smoke on immunity, inflammation and autoimmunity. J Autoimmun 34(3):J258-J265

22. Sugiyama D, Nishimura K, Tamaki K, Tsuji G, Nakazawa T, Morinobu A, Kumagai S (2010) Impact of smoking as a risk factor for developing rheumatoid arthritis: a meta-analysis of observational studies. Ann Rheum Dis 69(1):70-81 
23. Lleo A, Battezzati PM, Selmi C, Gershwin ME, Podda M (2008) Is autoimmunity a matter of sex? Autoimmun Rev 7(8):626-630

24. Ahmed SA, Hissong BD, Verthelyi D, Donner K, Becker K, Karpuzoglu-Sahin E (1999) Gender and risk of autoimmune diseases: possible role of estrogenic compounds. Environ Health Perspect 107(Suppl 5):681-686

25. Cooper GS, Parks CG (2004) Occupational and environmental exposures as risk factors for systemic lupus erythematosus. Curr Rheumatol Rep 6(5):367-374

26. Parks CG, Conrad K, Cooper GS (1999) Occupational exposure to crystalline silica and autoimmune disease. Environ Health Perspect 107(Suppl 5):793-802

27. Pfau JC, Brown JM, Holian A (2004) Silica-exposed mice generate autoantibodies to apoptotic cells. Toxicology 195(2-3): $167-176$

28. Brown JM, Archer AJ, Pfau JC, Holian A (2003) Silica accelerated systemic autoimmune disease in lupus-prone New Zealand mixed mice. Clin Exp Immunol 131(3):415-421

29. Parks CG, Cooper GS (2006) Occupational exposures and risk of systemic lupus erythematosus: a review of the evidence and exposure assessment methods in population- and clinic-based studies. Lupus 15(11):728-736

30. Kaplan MM, Gershwin ME (2005) Primary biliary cirrhosis. N Engl J Med 353(12):1261-1273

31. Hohenester S, Oude-Elferink RP, Beuers U (2009) Primary biliary cirrhosis. Semin Immunopathol 31(3):283-307

32. Lindor KD, Gershwin ME, Poupon R, Kaplan M, Bergasa NV, Heathcote EJ (2009) Primary biliary cirrhosis. Hepatology 50(1):291-308. doi:10.1002/hep.22906

33. Mitchison HC, Bassendine MF, Hendrick A, Bennett MK, Bird G, Watson AJ, James OF (1986) Positive antimitochondrial antibody but normal alkaline phosphatase: is this primary biliary cirrhosis? Hepatology 6(6):1279-1284

34. Neuberger J (1997) Primary biliary cirrhosis. Lancet 350(9081): 875-879

35. Prince MI, Chetwynd A, Craig WL, Metcalf JV, James OF (2004) Asymptomatic primary biliary cirrhosis: clinical features, prognosis, and symptom progression in a large population based cohort. Gut 53(6):865-870

36. Bogdanos DP, Komorowski L (2011) Disease-specific autoantibodies in primary biliary cirrhosis. Clin Chim Acta 412(7-8): 502-512

37. Bogdanos DP, Invernizzi P, Mackay IR, Vergani D (2008) Autoimmune liver serology: current diagnostic and clinical challenges. World J Gastroenterol 14(21):3374-3387

38. Bogdanos DP, Baum H, Vergani D (2003) Antimitochondrial and other autoantibodies. Clin Liver Dis 7(4):759-777 vi

39. Kumagi T, Heathcote EJ (2008) Primary biliary cirrhosis. Orphanet J Rare Dis 3:1

40. Gershwin ME, Mackay IR (2008) The causes of primary biliary cirrhosis: convenient and inconvenient truths. Hepatology 47(2): 737-745

41. Gershwin ME, Mackay IR (1991) Primary biliary cirrhosis: paradigm or paradox for autoimmunity. Gastroenterology 100(3):822-833

42. Dahnrich C, Pares A, Caballeria L, Rosemann A, Schlumberger W, Probst C, Mytilinaiou M, Bogdanos D, Vergani D, Stocker W, Komorowski L (2009) New ELISA for detecting primary biliary cirrhosis-specific antimitochondrial antibodies. Clin Chem 55(5):978-985

43. Liu H, Norman GL, Shums Z, Worman HJ, Krawitt EL, Bizzaro N, Vergani D, Bogdanos DP, Dalekos GN, Milkiewicz P, Czaja AJ, Heathcote EJ, Hirschfield GM, Tan EM, Miyachi K, Bignotto M, Battezzati PM, Lleo A, Leung PS, Podda M, Gershwin ME, Invernizzi P (2010) PBC screen: an IgG/IgA dual isotype ELISA detecting multiple mitochondrial and nuclear autoantibodies specific for primary biliary cirrhosis. J Autoimmun 35(4): $436-442$

44. Rigopoulou EI, Davies ET, Bogdanos DP, Liaskos C, Mytilinaiou M, Koukoulis GK, Dalekos GN, Vergani D (2007) Antimitochondrial antibodies of immunoglobulin G3 subclass are associated with a more severe disease course in primary biliary cirrhosis. Liver Int 27(9):1226-1231

45. Rigopoulou EI, Bogdanos DP, Liaskos C, Koutsoumpas A, Baum H, Vergani D, Dalekos GN (2007) Anti-mitochondrial antibody immunofluorescent titres correlate with the number and intensity of immunoblot-detected mitochondrial bands in patients with primary biliary cirrhosis. Clin Chim Acta 380(1-2): $118-121$

46. Gabeta S, Norman GL, Liaskos C, Papamichalis PA, Zografos T, Garagounis A, Rigopoulou EI, Dalekos GN (2007) Diagnostic relevance and clinical significance of the new enhanced performance M2 (MIT3) ELISA for the detection of IgA and $\mathrm{IgG}$ antimitochondrial antibodies in primary biliary cirrhosis. J Clin Immunol 27(4):378-387

47. Vergani D, Bogdanos DP (2003) Positive markers in AMAnegative PBC. Am J Gastroenterol 98(2):241-243

48. Van Norstrand MD, Malinchoc M, Lindor KD, Therneau TM, Gershwin ME, Leung PS, Dickson ER, Homburger HA (1997) Quantitative measurement of autoantibodies to recombinant mitochondrial antigens in patients with primary biliary cirrhosis: relationship of levels of autoantibodies to disease progression. Hepatology 25(1):6-11

49. Wesierska-Gadek J, Penner E, Battezzati PM, Selmi C, Zuin M, Hitchman E, Worman HJ, Gershwin ME, Podda M, Invernizzi P (2006) Correlation of initial autoantibody profile and clinical outcome in primary biliary cirrhosis. Hepatology 43(5): $1135-1144$

50. Bogdanos DP, Liaskos C, Pares A, Norman G, Rigopoulou EI, Caballeria L, Dalekos GN, Rodes J, Vergani D (2007) Antigp210 antibody mirrors disease severity in primary biliary cirrhosis. Hepatology 45(6):1583 (author reply 1583-1584)

51. Bogdanos DP, Liaskos C, Rigopoulou EI, Dalekos GN (2006) Anti-mitochondrial antibodies in patients with systemic lupus erythematosus: revealing the unforeseen. Clin Chim Acta 373(1-2):183-184 (author reply 185)

52. Bogdanos DP, Pares A, Rodes J, Vergani D (2004) Primary biliary cirrhosis specific antinuclear antibodies in patients from Spain. Am J Gastroenterol 99(4):763-764 (author reply 765)

53. Bogdanos DP, Vergani D, Muratori P, Muratori L, Bianchi FB (2004) Specificity of anti-sp100 antibody for primary biliary cirrhosis. Scand J Gastroenterol 39(4):405-406 (author reply 407)

54. Courvalin JC, Worman HJ (1997) Nuclear envelope protein autoantibodies in primary biliary cirrhosis. Semin Liver Dis 17(1):79-90

55. Invernizzi P, Crosignani A, Battezzati PM, Covini G, De Valle G, Larghi A, Zuin M, Podda M (1997) Comparison of the clinical features and clinical course of antimitochondrial antibody-positive and -negative primary biliary cirrhosis. Hepatology 25(5):1090-1095

56. Invernizzi P, Podda M, Battezzati PM, Crosignani A, Zuin M, Hitchman E, Maggioni M, Meroni PL, Penner E, WesierskaGadek J (2001) Autoantibodies against nuclear pore complexes are associated with more active and severe liver disease in primary biliary cirrhosis. J Hepatol 34(3):366-372

57. Miyachi K, Hankins RW, Matsushima H, Kikuchi F, Inomata T, Horigome T, Shibata M, Onozuka Y, Ueno Y, Hashimoto E, Hayashi N, Shibuya A, Amaki S, Miyakawa H (2003) Profile and clinical significance of anti-nuclear envelope antibodies found in patients with primary biliary cirrhosis: a multicenter study. J Autoimmun 20(3):247-254 
58. Muratori P, Muratori L, Ferrari R, Cassani F, Bianchi G, Lenzi M, Rodrigo L, Linares A, Fuentes D, Bianchi FB (2003) Characterization and clinical impact of antinuclear antibodies in primary biliary cirrhosis. Am J Gastroenterol 98(2): 431-437

59. Rigopoulou EI, Davies ET, Pares A, Zachou K, Liaskos C, Bogdanos DP, Rodes J, Dalekos GN, Vergani D (2005) Prevalence and clinical significance of isotype specific antinuclear antibodies in primary biliary cirrhosis. Gut 54(4):528-532

60. Szostecki C, Guldner HH, Will H (1997) Autoantibodies against "nuclear dots" in primary biliary cirrhosis. Semin Liver Dis 17(1):71-78

61. Bogdanos DP, Mieli-Vergani G, Vergani D (2009) Autoantibodies and their antigens in autoimmune hepatitis. Semin Liver Dis 29(3):241-253

62. Mytilinaiou MG, Bogdanos DP (2009) Primary biliary cirrhosisspecific autoantibodies in patients with systemic sclerosis. Dig Liver Dis Off J Italian Soc Gastroenterol Italian Assoc Study Liver 41(12):916 (author reply 916-917)

63. Bogdanos DP, Vergani D (2006) Origin of cross-reactive autoimmunity in primary biliary cirrhosis. Liver Int 26(6):633-635. doi:10.1111/j.1478-3231.2006.01291.x

64. Dubel L, Tanaka A, Leung PS, Van de Water J, Coppel R, Roche T, Johanet C, Motokawa Y, Ansari A, Gershwin ME (1999) Autoepitope mapping and reactivity of autoantibodies to the dihydrolipoamide dehydrogenase-binding protein (E3BP) and the glycine cleavage proteins in primary biliary cirrhosis. Hepatology 29(4):1013-1018

65. Leung PS, Coppel RL, Ansari A, Munoz S, Gershwin ME (1997) Antimitochondrial antibodies in primary biliary cirrhosis. Semin Liver Dis 17(1):61-69

66. Palmer JM, Jones DE, Quinn J, McHugh A, Yeaman SJ (1999) Characterization of the autoantibody responses to recombinant E3 binding protein (protein $\mathrm{X}$ ) of pyruvate dehydrogenase in primary biliary cirrhosis. Hepatology 30(1):21-26

67. Van de Water J, Fregeau D, Davis P, Ansari A, Danner D, Leung P, Coppel R, Gershwin ME (1988) Autoantibodies of primary biliary cirrhosis recognize dihydrolipoamide acetyltransferase and inhibit enzyme function. J Immunol 141(7): 2321-2324

68. Nakamura M, Kondo H, Mori T, Komori A, Matsuyama M, Ito M, Takii Y, Koyabu M, Yokoyama T, Migita K, Daikoku M, Abiru S, Yatsuhashi H, Takezaki E, Masaki N, Sugi K, Honda K, Adachi H, Nishi H, Watanabe Y, Nakamura Y, Shimada M, Komatsu T, Saito A, Saoshiro T, Harada H, Sodeyama T, Hayashi S, Masumoto A, Sando T, Yamamoto T, Sakai H, Kobayashi M, Muro T, Koga M, Shums Z, Norman GL, Ishibashi $H$ (2007) Anti-gp210 and anti-centromere antibodies are different risk factors for the progression of primary biliary cirrhosis. Hepatology 45(1):118-127

69. Smyk D, Grammatikopoulos T, Daponte A, Rigopoulou EI, Bogdanos DP (2011) Fetomaternal alloimmunity as a cause of liver disease. Autoimmun Highlights 2(1):29-33

70. de Carvalho JF, Rodrigues Pereira RM, Shoenfeld Y (2011) Pearls in autoimmunity. Autoimmun Highlights 2(1):1-4

71. van Dooren SHJ, van Venrooij WJ, Pruijn GJM (2011) Myositis-specific autoantibodies: detection and clinical associations. Autoimmun Highlights 1(2):5-20

72. Morozzi G, Bellisai F, Fineschi I, Scaccia F, Pucci G, Simpatico A, Tampoia M, Chialà A, Lapadula G, Galeazzi M (2011) Prevalence of anti-histone antibodies, their clinical significance and correlation with other autoantibodies in a cohort of Italian scleroderma patients. Autoimmun Highlights 2(1):29-33

73. Saverino D, Simone R, Bagnasco M, Pesce G (2010) The soluble CTLA-4 receptor and its role in autoimmune diseases: an update. Autoimmun Highlights 1(2):73-81
74. Zen M, Bassi N, Campana C, Bettio S, Tarricone E, Nalotto L, Ghirardello A, Doria A (2010) Protective molecules and their cognate antibodies: new players in autoimmunity. Autoimmun Highlights 1(2):63-72

75. Bosi E, Bianchi R, Ruotolo G, Bazzigaluppi E, Belloni C, Calori G, Girardi AM, Garancini MP, Scavini M (2010) Diagnostic sensitivity of thyroid autoantibodies assessed in a populationbased, cross-sectional study in adults. Autoimmun Highlights 1(2):83-86

76. Fabris M, De Vita S, Blasone N, Visentini D, Pezzarini E, Pontarini E, Fabro C, Quartuccio L, Mazzolini S, Curcio F, Tonutti E (2010) Serum levels of anti-CCP antibodies, antiMCV antibodies and RF IgA in the follow-up of patients with rheumatoid arthritis treated with rituximab. Autoimmun Highlights 1(2):87-94

77. Tozzoli R, Kodermaz G, Villalta D, Bagnasco M, Pesce G, Bizzaro N (2010) Accuracy of receptor-based methods for detection of thyrotropin-receptor autoantibodies: a new automated third-generation immunoassay shows higher analytical and clinical sensitivity for the differential diagnosis of hyperthyroidism. Autoimmun Highlights 1(2):95-100

78. Bizzaro N (2010) Autoimmunity highlights: a bridge between the clinic and the laboratory. Autoimmun Highlights 1(1):1-2

79. Favaloro EJ, Wong RCW (2010) The antiphospholipid syndrome: a large elephant with many parts or an elusive chameleon disguised by many colours? Autoimmun Highlights 1(1):5-14

80. Espinosa G, Cervera R (2010) Management of the antiphospholipid syndrome. Autoimmun Highlights 1(1):15-22

81. Böckle BC, Sepp NT (2010) Hepatitis C virus and autoimmunity. Autoimmun Highlights 1(1):23-35

82. Csernok E, Holle JU (2010) Twenty-eight years with antineutrophil cytoplasmic antibodies (ANCA): how to test for ANCA-evidence-based immunology? Autoimmun Highlights 1(1):39-43

83. Rostami K, Dulaimi DA, Nejad MR, Villanacci V, Danciu M (2010) Microscopic enteritis and pathomechanism of malabsorption. Autoimmun Highlights 1(1):37-38

84. Vergani D, Bogdanos DP, Baum H (2004) Unusual suspects in primary biliary cirrhosis. Hepatology 39(1):38-41

85. Wen L, Ma Y, Bogdanos DP, Wong FS, Demaine A, MieliVergani G, Vergani D (2001) Pediatric autoimmune liver diseases: the molecular basis of humoral and cellular immunity. Curr Mol Med 1(3):379-389

86. Vergani D, Longhi MS, Bogdanos DP, Ma Y, Mieli-Vergani G (2009) Autoimmune hepatitis. Semin Immunopathol 31(3): 421-435

87. Ma Y, Thomas MG, Okamoto M, Bogdanos DP, Nagl S, Kerkar N, Lopes AR, Muratori L, Lenzi M, Bianchi FB, Mieli-Vergani G, Vergani D (2002) Key residues of a major cytochrome P4502D6 epitope are located on the surface of the molecule. J Immunol 169(1):277-285

88. Kerkar N, Choudhuri K, Ma Y, Mahmoud A, Bogdanos DP, Muratori L, Bianchi F, Williams R, Mieli-Vergani G, Vergani D (2003) Cytochrome P4502D6(193-212): a new immunodominant epitope and target of virus/self cross-reactivity in liver kidney microsomal autoantibody type 1-positive liver disease. J Immunol 170(3):1481-1489

89. Bogdanos DP, Choudhuri K, Vergani D (2001) Molecular mimicry and autoimmune liver disease: virtuous intentions, malign consequences. Liver 21(4):225-232

90. Bogdanos DP, Baum H, Grasso A, Okamoto M, Butler P, Ma Y, Rigopoulou E, Montalto P, Davies ET, Burroughs AK, Vergani D (2004) Microbial mimics are major targets of crossreactivity with human pyruvate dehydrogenase in primary biliary cirrhosis. J Hepatol 40(1):31-39 
91. Van de Water J, Ishibashi H, Coppel RL, Gershwin ME (2001) Molecular mimicry and primary biliary cirrhosis: premises not promises. Hepatology 33(4):771-775

92. Shimoda S, Nakamura M, Shigematsu H, Tanimoto H, Gushima T, Gershwin ME, Ishibashi H (2000) Mimicry peptides of human PDC-E2 163-176 peptide, the immunodominant T-cell epitope of primary biliary cirrhosis. Hepatology 31(6):1212-1216

93. Bogdanos DP, Baum H, Sharma UC, Grasso A, Ma Y, Burroughs AK, Vergani D (2002) Antibodies against homologous microbial caseinolytic proteases $\mathrm{P}$ characterise primary biliary cirrhosis. J Hepatol 36(1):14-21

94. Bogdanos DP, Mieli-Vergani G, Vergani D (2000) Virus, liver and autoimmunity. Dig Liver Dis 32(5):440-446

95. Bogdanos DP, Baum H, Okamoto M, Montalto P, Sharma UC, Rigopoulou EI, Vlachogiannakos J, Ma Y, Burroughs AK, Vergani D (2005) Primary biliary cirrhosis is characterized by IgG3 antibodies cross-reactive with the major mitochondrial autoepitope and its Lactobacillus mimic. Hepatology 42(2): 458-465

96. Bogdanos DP, Koutsoumpas A, Baum H, Vergani D (2006) Borrelia burgdorferi: a new self-mimicking trigger in primary biliary cirrhosis. Dig Liver Dis 38(10):781-782 (author reply 782-783)

97. Koutsoumpas A, Mytilinaiou M, Polymeros D, Dalekos GN, Bogdanos DP (2009) Anti-Helicobacter pylori antibody responses specific for VacA do not trigger primary biliary cirrhosis-specific antimitochondrial antibodies. Eur J Gastroenterol Hepatol 21(10): 1220

98. Koutsoumpas A, Polymeros D, Tsiamoulos Z, Smyk D, Karamanolis G, Triantafyllou K, Rigopoulou EI, Forbes A, Vergani D, Bogdanos DP, Ladas SD (2011) Peculiar antibody reactivity to human connexin 37 and its microbial mimics in patients with Crohn's disease. J Crohns Colitis 5(2):101-109

99. Bogdanos DP, Smith H, Ma Y, Baum H, Mieli-Vergani G, Vergani D (2005) A study of molecular mimicry and immunological cross-reactivity between hepatitis B surface antigen and myelin mimics. Clin Dev Immunol 12(3):217-224

100. Bogdanos DP, Dalekos GN (2008) Enzymes as target antigens of liver-specific autoimmunity: the case of cytochromes P450s. Curr Med Chem 15(22):2285-2292

101. Bogdanos DP, Baum H, Vergani D, Burroughs AK (2010) The role of $E$. coli infection in the pathogenesis of primary biliary cirrhosis. Dis Markers 29(6):301-311

102. Bogdanos DP, Vergani D (2006) Origin of cross-reactive autoimmunity in primary biliary cirrhosis. Liver Int 26(6):633-635. doi:10.1111/j.1478-3231.2006.01291.x

103. Bogdanos DP, Vergani D (2009) Bacteria and primary biliary cirrhosis. Clin Rev Allergy Immunol 36(1):30-39. doi:10.1007/ s12016-008-8087-9

104. Jones DE (2007) Pathogenesis of primary biliary cirrhosis. Gut 56(11):1615-1624. doi:10.1136/gut.2007.122150

105. Bogdanos DP, Baum H, Gunsar F, Arioli D, Polymeros D, Ma Y, Burroughs AK, Vergani D (2004) Extensive homology between the major immunodominant mitochondrial antigen in primary biliary cirrhosis and Helicobacter pylori does not lead to immunological cross-reactivity. Scand J Gastroenterol 39(10): 981-987. doi:10.1080/00365520410003236

106. Bogdanos DP, Pares A, Baum H, Caballeria L, Rigopoulou EI, Ma Y, Burroughs AK, Rodes J, Vergani D (2004) Diseasespecific cross-reactivity between mimicking peptides of heat shock protein of Mycobacterium gordonae and dominant epitope of E2 subunit of pyruvate dehydrogenase is common in Spanish but not British patients with primary biliary cirrhosis. J Autoimmun 22(4):353-362. doi:10.1016/j.jaut.2004.03.002

107. Muratori L, Bogdanos DP, Muratori P, Lenzi M, Granito A, Ma Y, Mieli-Vergani G, Bianchi FB, Vergani D (2005)
Susceptibility to thyroid disorders in hepatitis C. Clin Gastroenterol Hepatol 3(6):595-603

108. Polymeros D, Bogdanos DP, Day R, Arioli D, Vergani D, Forbes A (2006) Does cross-reactivity between mycobacterium avium paratuberculosis and human intestinal antigens characterize Crohn's disease? Gastroenterology 131(1):85-96

109. Burroughs AK, Rosenstein IJ, Epstein O, Hamilton-Miller JM, Brumfitt W, Sherlock S (1984) Bacteriuria and primary biliary cirrhosis. Gut 25(2):133-137

110. Butler P, Valle F, Hamilton-Miller JM, Brumfitt W, Baum H, Burroughs AK (1993) M2 mitochondrial antibodies and urinary rough mutant bacteria in patients with primary biliary cirrhosis and in patients with recurrent bacteriuria. J Hepatol 17(3): 408-414

111. Selmi C, Meda F, Kasangian A, Invernizzi P, Tian Z, Lian Z, Podda M, Gershwin ME (2010) Experimental evidence on the immunopathogenesis of primary biliary cirrhosis. Cell Mol Immunol 7(1):1-10

112. Selmi C, Gershwin ME (2009) The role of environmental factors in primary biliary cirrhosis. Trends Immunol 30(8):415-420

113. Prince MI, Ducker SJ, James OF (2010) Case-control studies of risk factors for primary biliary cirrhosis in two United Kingdom populations. Gut 59(4):508-512

114. Ala A, Stanca CM, Bu-Ghanim M, Ahmado I, Branch AD, Schiano TD, Odin JA, Bach N (2006) Increased prevalence of primary biliary cirrhosis near Superfund toxic waste sites. Hepatology 43(3):525-531

115. Triger DR (1980) Primary biliary cirrhosis: an epidemiological study. Br Med J 281(6243):772-775

116. Corpechot C, Chretien Y, Chazouilleres O, Poupon R (2010) Demographic, lifestyle, medical and familial factors associated with primary biliary cirrhosis. J Hepatol 53(1):162-169

117. Cooper GS, Dooley MA, Treadwell EL, St Clair EW, Gilkeson GS (2001) Smoking and use of hair treatments in relation to risk of developing systemic lupus erythematosus. J Rheumatol 28(12):2653-2656

118. Cooper GS, Parks CG, Schur PS, Fraser PA (2006) Occupational and environmental associations with antinuclear antibodies in a general population sample. J Toxicol Environ Health A 69(23):2063-2069

119. Freni-Titulaer LW, Kelley DB, Grow AG, McKinley TW, Arnett FC, Hochberg MC (1989) Connective tissue disease in southeastern Georgia: a case-control study of etiologic factors. Am J Epidemiol 130(2):404-409

120. Jimenez-Alonso J, Sabio JM, Perez-Alvarez F, Reche I, Hidalgo C, Jaimez L (2002) Hair dye treatment use and clinical course in patients with systemic lupus erythematosus and cutaneous lupus. Lupus 11(7):430-434

121. Mayes MD (1999) Epidemiologic studies of environmental agents and systemic autoimmune diseases. Environ Health Perspect 107(Suppl 5):743-748

122. Petri M, Allbritton J (1992) Hair product use in systemic lupus erythematosus. A case-control study. Arthritis Rheum 35(6): 625-629

123. Price EJ, Venables PJ (1995) Drug-induced lupus. Drug Saf 12(4):283-290

124. Rubin IM, Dabelsteen S, Nielsen MM, White IR, Johansen JD, Geisler C, Bonefeld CM (2010) Repeated exposure to hair dye induces regulatory $\mathrm{T}$ cells in mice. $\mathrm{Br} \mathrm{J}$ Dermatol 163(5): 992-998

125. Sanchez-Guerrero J, Karlson EW, Colditz GA, Hunter DJ, Speizer FE, Liang MH (1996) Hair dye use and the risk of developing systemic lupus erythematosus. Arthritis Rheum 39(4):657-662

126. Wang D, Zhang H, Liang J, Gu Z, Zhou Q, Fan X, Hou Y, Sun L (2010) CD4+ CD25+ but not CD4+ Foxp3+ T cells as a 
regulatory subset in primary biliary cirrhosis. Cell Mol Immunol 7(6):485-490

127. Aoki CA, Roifman CM, Lian ZX, Bowlus CL, Norman GL, Shoenfeld Y, Mackay IR, Gershwin ME (2006) IL-2 receptor alpha deficiency and features of primary biliary cirrhosis. J Autoimmun 27(1):50-53

128. Bernuzzi F, Fenoglio D, Battaglia F, Fravega M, Gershwin ME, Indiveri F, Ansari AA, Podda M, Invernizzi P, Filaci G (2010) Phenotypical and functional alterations of CD8 regulatory $\mathrm{T}$ cells in primary biliary cirrhosis. J Autoimmun 35(3):176-180
129. Zhang W, Sharma R, Ju ST, He XS, Tao Y, Tsuneyama K, Tian Z, Lian ZX, Fu SM, Gershwin ME (2009) Deficiency in regulatory $\mathrm{T}$ cells results in development of antimitochondrial antibodies and autoimmune cholangitis. Hepatology 49(2):545-552

130. Wakabayashi K, Lian ZX, Moritoki Y, Lan RY, Tsuneyama K, Chuang YH, Yang GX, Ridgway W, Ueno Y, Ansari AA, Coppel RL, Mackay IR, Gershwin ME (2006) IL-2 receptor alpha $(-/-)$ mice and the development of primary biliary cirrhosis. Hepatology 44(5):1240-1249 